\title{
Use of hydrogel in the irrigation management of white pitaya (Hylocereus undatus) seedlings: Biometrics and accumulation of organic and inorganic solutes
}

\author{
Uso do hidrogel no manejo da irrigação de mudas \\ de pitaya branca (Hylocereus undatus): Biometria e \\ acúmulo de solutos orgânicos e inorgânicos
}

\begin{abstract}
Maria Fgênia Saldanha Diógenes"; Vander Mendonça ${ }^{2}$; Luciana Freitas de Medeiros Mendonça3; Elias Ariel de Moura4; Keivianne da Silva Lima Reges"; Luana Mendes de Oliveira4; Agda Malany Forte de Oliveira ${ }^{4 *}$
\end{abstract}

\section{Highlights}

Hydrogel incorporation into the substrate improved the nutrient content.

The irrigation frequency of about 3 days provided a better seedling development.

Daily irrigation negatively affected the development of pitayas.

\begin{abstract}
The initial development of pitayas may be limited by a few factors, among them, water deficit. Agricultural hydrogels can be used as an alternative to enhance the retention and availability of water and nutrients in the soil. Therefore, this study aimed to evaluate the influence of irrigation frequency and hydrogel doses on the development of white pitaya (Hylocereus undatus) seedlings to establish a time interval in days between irrigations that provides better seedling development and determine the hydrogel dose that provides a reduction of water consumption without damaging seedling development. The experimental design consisted of randomized blocks in a $4 \times 4$ factorial arrangement, in which the treatments corresponded to 4 hydrogel doses $(0,2,4$, and $6 \mathrm{~g}$ /plant of Biogel Hidro Plus) incorporated into the substrate and four irrigation frequencies $(1,3,5$, and 7 days of interval). The biometric characteristics, photosynthetic pigments, and organic and inorganic solutes of the plants were evaluated after 120 days. The use of daily irrigation negatively influenced the growth and biomass accumulation of the aerial part of the seedlings and, consequently, provided the lowest values of cladodes of the pitaya seedlings. Pitaya seedlings had

1 Master in Phytotechnics, Universidade Federal Rural do Semi-Árido, UFERSA, Mossoró, RN, Brazil. E-mail: mariafgenia@hotmail.com

2 Prof. Dr., Department of Phytotechnics, UFERSA, Mossoró, RN, Brazil. E-mail: vanderm2000@hotmail.com

${ }^{3}$ Profa ${ }^{\text {Dra }}$, Center for Health and Rural Technology, Universidade Federal de Campina Grande, UFCG, Patos, PB, Brazil. E-mail: lucisfreitas@hotmail.com

${ }^{4}$ Students of the Doctoral Course of the Postgraduate Program in Plant Science, UFERSA, Mossoró, RN, Brazil. E-mail: ariel.agro90@hotmail.com; kei.v@hotmail.com; lul-ut@hotmail.com; agdamalany@hotmail.com

* Author for correspondence
\end{abstract}

Received: Apr. 27, 2021 - Approved: Nov. 17, 2021 
greater development when using an irrigation frequency of around 3 days. The application of $6 \mathrm{~g} / \mathrm{plant}$ of hydrogel provided the highest averages for accumulation of dry biomass, photosynthetic pigments, and organic and inorganic solutes at irrigation levels of 3.6, 4, and about 3.8 days of intervals, respectively. Hydrogel incorporation allowed increasing the interval between irrigations by 1 day without damages to the seedling development.

Key words: Hydrogel. Hylocereus undatus. Irrigation frequency. Propagation. Water deficit.

\section{Resumo}

O desenvolvimento inicial das pitayas pode ser limitado por alguns fatores, entre eles, a escassez de água. Os hidrogeis agrícolas podem ser usados como alternativa para aumentar a retenção e a disponibilidade de água e nutrientes no solo. Portanto, este trabalho teve como objetivo avaliar a influência da frequência de irrigação e das doses de hidrogel no desenvolvimento de mudas de pitaya branca (Hylocereus undatus) para estabelecer um intervalo de tempo em dias entre as irrigações que proporcione melhor desenvolvimento das mudas e determinar a dose de hidrogel que proporcione uma redução de consumo de água sem prejudicar o desenvolvimento das mudas. O delineamento experimental consistiu em blocos casualizados em esquema fatorial $4 \times 4$, em que os tratamentos corresponderam a 4 doses de hidrogel $(0,2,4$ e $6 \mathrm{~g} /$ planta de Biogel Hidro Plus) incorporados ao substrato e quatro frequências de irrigação (1, 3, 5 e 7 dias de intervalo). As características biométricas, pigmentos fotossintéticos e solutos orgânicos e inorgânicos das plantas foram avaliados após 120 dias. O uso da irrigação diária influenciou negativamente no crescimento e no acúmulo de biomassa da parte aérea das mudas e, consequentemente, proporcionou os menores valores de cladódios das mudas de pitaya. As mudas de pitaya tiveram maior desenvolvimento com a frequência de irrigação em torno de 3 dias. A aplicação de $6 \mathrm{~g} /$ planta de hidrogel proporcionou as maiores médias de acúmulo de biomassa seca, pigmentos fotossintéticos e solutos orgânicos e inorgânicos em níveis de irrigação de 3,6, 4 e cerca de 3,8 dias de intervalo, respectivamente. A incorporação do hidrogel permitiu aumentar o intervalo entre as irrigações em 1 dia sem prejuízo ao desenvolvimento das mudas.

Palavras-chave: Déficit de água. Frequência de irrigação. Hydrogel. Hylocereus undatus. Propagação.

\section{Introduction}

Hydrogels are water-retainer polymers, powder, and granules and form a transparent gel body in which roots develop. This substance is made up of a synthetically developed polyacrylamide base, which can retain water. It can be mixed with soil or substrate to change its physical and chemical properties and increase water retention and nutrient absorption (Aleman, Campos, \& Mantovani, 2020).
Pitaya cultivation is a promising alternative within the group of tropical fruits due to its rusticity and ability to adapt to different environments. Recently, it has occupied a growing niche in the European exotic fruit market, being sought not only for its exotic appearance but also for the organoleptic characteristics of its fruits (Silva, Martins, \& Cavallari, 2011). In Brazil, its cultivation is relatively new, but its production has already reached expressive values. According to Companhia Nacional de Abastecimento 
(CONAB), pitaya generated revenue of $\mathrm{R} \$$ 24 million in 2019, representing an increase of $264 \%$ compared to 2017 (Companhia Nacional de Abastecimento [CONAB], 2020). However, despite the valuable interest in this fruit crop, studies on its initial development concerning water and nutritional issues and stress conditions are still scarce.

Seedling production is an important requirement at the time of implementation of an orchard. The development of good quality seedlings reflects directly on the productivity and quality of the final product. In addition, another limiting factor is the water availability since its lack or excess can compromise seedling growth and development, thus affecting productivity in the field.

Hydro-absorbent polymers stand out among the most studied products as an alternative to optimize seedling production and minimize water use. These polymers favor water retention (about 90-95\%) when incorporated into the substrate, and the water absorbed by the hydrogel particles can be released gradually to the plant. Therefore, the hydrogel application may allow longer intervals between irrigations, adequately meeting the water and nutrient needs for seedlings (Bernardi, Sperotto, Daniel, \& Vitorino, 2012; Abdallah, 2019).

The use of this polymer has grown significantly over the years in Brazilian agriculture, mainly due to the promising results observed in some studies evaluating sweet and yellow passion fruit (Hafle, Cruz, Ramos, Ramos, \& Santos, 2008; Carvalho, Cruz, \& Martins, 2013), 'Cleopatra' mandarin rootstock (Cruz, Hafle, Ramos, \& Ramos, 2008), and blackberry seedlings (Moreira, Ramos, Cruz, Villar, \& Hafle, 2010). However, there is interest to elucidate the applicability of hydrogel, as its benefits depend on the application method, the used quantity, and the objective to be achieved (Monteiro, 2017).

Recently, research related to the production of pitaya seedlings has been mostly concentrated on determining the length of cladodes for vegetative propagation and its influence on their initial development, with few studies on the behavior of this species related to water availability. Therefore, this study aimed to evaluate the influence of irrigation frequency and hydrogel doses on the development of white pitaya (Hylocereus undatus) seedlings, seeking to establish a time interval in days between irrigations that provides better seedling development and determine the hydrogel dose that provides water reduction without harming seedling development.

\section{Materials and Methods}

\section{Experimental conduct}

The experiment was carried out in a $50 \%$ shade greenhouse (with screen) in the seedling production sector of the Universidade Federal Rural do Semi-Árido (UFERSA), located in Mossoro, Rio Grande do Norte, Brazil. This protected environment reached maximum, minimum, and mean temperatures of 41.4 , 23.4 , and $32.4{ }^{\circ} \mathrm{C}$ and relative humidity of the air of $69 \%$ during the experimental period.

The substrate consisted of a mixture of sand and organic compound at a 3:1 (v/v) ratio, respectively. Substrate fertility attributes are shown in Supplementary Material: Table 1. The analyses were carried out at the Laboratory of Soils of UFERSA, according to the EMBRAPA 
methodologies (Teixeira,
Fontana, \& Teixeira, 2017).

The hydrogel was dry incorporated into the substrate. Hydration was performed by applying water to 2-kg black plastic bags measuring $28 \mathrm{~cm} \times 15 \mathrm{~cm} \times 0.15 \mathrm{~mm}$ (with and without hydrogel) until complete hydration. Irrigation was performed manually, keeping the substrate at around $60 \%$ field capacity (FC) using a weighing lysimeter.

\section{Experimental design}

The experimental design consisted of randomized blocks in a $4 \times 4$ factorial arrangement [four doses of Biogel Hidro Plus polymer (Mossoro, Brazil) (0, 2, 4, and $6 \mathrm{~g}$ /plant) and four irrigation frequencies (daily irrigation, irrigation every three days, irrigation every five days, and irrigation every seven days)], with four replications and four plants per plot, totalizing 256 plants.

\section{Scientific analysis}

The biometric characteristics, photosynthetic pigments, and organic and inorganic solutes of the plants were evaluated after 120 days The biometry, chloroplast pigments, and organic and inorganic solutes of the plants were evaluated after 120 days after cladode transplanting.
Morphometric analysis

The following parameters were evaluated for biometry: length of the sum of cladodes and length of the largest root $(\mathrm{cm})$, cladode diameter and thickness $(\mathrm{mm})$, cladode dry and fresh matter (g), root system dry matter (g), total dry matter (g), and aerial part to root dry matter ratio.

The cladode diameter and thickness were measured with a digital caliper (Mtx, 316119) with a precision of $0.01 \mathrm{~mm}$, being performed in half of the cladode length. The aerial part length was measured from the insertion of the sprouted cladode to the apical end, while the root system length was measured from the root insertion to the largest root end. The length measurements were performed using a graduated ruler (cm).

\section{Biochemical analyses}

The biochemical analyses performed were chlorophyll a, chlorophyll b, total chlorophyll, carotenoids, proline, and total amino acids.

The following equations were used to determine the chlorophyll content (Arnon, 1949; Witham, Blaydes, \& Devlin, 1971), and the equation described by Lichtenthaler (1987) was used to determine the carotenoid content:

$$
\begin{gathered}
C L a=\left(\left(12.7 * A_{663}\right)-\left(2.69 * A_{645}\right)\right) * \frac{V}{1000 * W} \\
C L b=\left(\left(22.9 * A_{645}\right)-\left(4.68 * A_{663}\right)\right) * \frac{V}{1000 * W} \\
C L \text { total }=\left(\left(20.2 * A_{645}\right)-\left(8.02 * A_{663}\right)\right) * \frac{V}{1000 * W} \\
\text { Total carotenoide }=\left(\left(1000 * A_{470}\right)-(1.82 * C L a)-(85.02 * C L b)\right) / 198
\end{gathered}
$$


where $A$ is the absorbance reading at the indicated wavelength, $\mathrm{V}$ is the volume at the end of the used extract, and $W$ is the weight of the used fresh material.

After chlorophyll extraction, the precipitate was vortexed with a $0.1 \mathrm{M}$ monobasic potassium phosphate buffer solution. Then, the material was centrifuged at $10.000 \times \mathrm{g}$ for 5 minutes. The supernatant was removed and stored at $25^{\circ} \mathrm{C}$ until amino acids determination, as previously described by Yemm, Cocking and Ricketts (1955). Proline was determined according to the methodology described by Silveira et al. (2003), and total soluble sugars according to Yemm and Willis (1954). Samples were quantified in a mass spectrophotometer (Cary 60, Agilent) at 520 $\mathrm{nm}$ length and the results were expressed in micrograms of proline per gram of fresh matter.

\section{Nutritional analysis}

Nitrogen, phosphorus, potassium, calcium, and magnesium contents were determined. Nitrogen was determined by the Kjeldahl method (sulfuric digestion $=\mathrm{H}_{2} \mathrm{SO}_{4}$ $+\mathrm{H}_{2} \mathrm{O}_{2}$ ). Potassium, phosphorus, calcium, and magnesium were determined (nitroperchloric digestion $=\mathrm{HNO}_{3}+\mathrm{HClO}_{4}$ ) using the microwave heating digestion technique, using the MARSR ${ }^{\text {TM }}$ digester manufactured by CEM Corporation. The readings were performed using ICP 5110 - OES manufactured by Agilent (Empresa Brasileira de Pesquisa Agropecuária [EMBRAPA], 2013).

\section{Statistical analysis}

The data obtained from the variables were submitted to the Shapiro-Wilk normality test and the Bartlett homogeneity test ( $p<$ 0.05), followed by an analysis of variance when within normality and homogeneity standards. The evaluated variables were submitted to analysis of variance by the F-test ( $p<0.01$ and $p<0.05$ ), followed by regression analysis $(p<0.05)$ when significant. The analyses were performed in the statistical program $\mathrm{R}$ Core (R Core Team $[R], 2018$ ), using the statistical package Expdes.pt. (Ferreira, Cavalcanti, \& Nogueira, 2018). The software Sigma Plot was used to construct the graphs.

\section{Results and Discussion}

\section{Morphometric characteristics}

The morphometric characteristics cladode diameter (CD), cladode thickness (CT), aerial part fresh matter (APFM), aerial part dry matter (APDM), and length of the sum of cladodes (LSC) showed a significant effect only for the isolated factor irrigation frequency (IF) ( $p<0.01$; $p<0.05$ ). The variables total dry matter (TDM), root dry matter (RDM), root length $(R L)$, and aerial part to root system ratio (APRR) showed a significant interaction between irrigation frequency (IF) and hydrogel doses (HD) ( $p<0.01$; $p<0.05$ ) (Supplementary Material: Table 2).

The reduction in irrigation frequency influenced the diameter and thickness attributes of the studied seedlings. Both variables showed a linear effect, in which the cladode diameter (CD) decreased linearly with a reduction in irrigation frequency, with the 
highest result observed in the daily irrigation frequency. On the other hand, the cladode thickness (CT) showed a reverse effect, increasing linearly with a reduction in irrigation frequency up to 7 days (Figures $1 \mathrm{~A}$ and 1B).

The lower irrigation frequency resulted in smaller seedling diameters, the reverse being true for cladode thickness. This limitation in cladode diameter may be related to an increase in the interval between irrigations, causing a reduction in vegetative and reproductive growth due to the decrease in the water volume available to the plant, which affects cell division and elongation (Taiz, Zeiger, Moller, \& Murphy, 2017).

Similarly, limited water availability in the soil can modulate drought tolerance mechanisms by the plant to reduce water loss under water deficiency conditions. The higher cladode thickness can be a photoprotective mechanism of the plant against excess light, reducing water loss and protecting photosynthetic tissues (García Aguilar, Terrazas, \& Arias, 2009; Almeida, 2015).

The increase in the external thickness of the epidermis and cuticle, probably as a way to reduce cuticular transpiration, has already been observed in different species such as Olea europaea and Manihot esculenta, under water deficit conditions (Ennajeh, Vadel, Cochard, \& Hemira, 2010; Ribeiro, Carvalho, Pereira, \& Castro, 2012).

The means of the aerial part fresh matter (APFM), aerial part dry matter (APDM), and length of the sum of cladode (LSC) (Figure $1 \mathrm{C}, 1 \mathrm{D}$, and $1 \mathrm{E}$ ) were adjusted to a quadratic polynomial regression model. The maximum values of 206.8 and $11.8 \mathrm{~g} /$ plant for APFM and APDM, respectively, were obtained at irrigation frequencies of 3.6 and 3.2 days (Figure $1 \mathrm{C}$ and 1D). The maximum cladode length of 114.52 $\mathrm{cm}$ was obtained at an irrigation frequency of 3.6 days (Figure 1E). There were decreases with a reduction in irrigation frequency, with the lowest means observed in plants submitted to the highest interval between irrigations (7 days).

Daily irrigation frequency negatively affected growth and biomass accumulation of the aerial part, leading to values of cladode length $(96.35 \mathrm{~cm})$ and aerial part fresh $(173.33$ g/plant) and dry biomass accumulation (11.08 $\mathrm{g} /$ plant) similar to those obtained at the lowest irrigation frequency (7 days).

The lower aerial part biomass accumulation can be attributed to the water deficit resulting from the low soil water availability as irrigation frequency was reduced. These results may be due to a reduction in the photosynthetic activity of the plant due to the lower nutritional input, which negatively interferes with the growth, size, and structure of leaves, stems, and roots, thus causing a decrease in plant biomass (Larcher, 2000).

The absence and application of hydrogel (4 and $6 \mathrm{~g} / \mathrm{plant}$ ) in the root system length (RL) (Figure $2 \mathrm{~A}$ ) were adjusted to a positive quadratic polynomial regression model, and the highest means were obtained in plants submitted to the most severe water deficit at the irrigation frequency of 7 days. The most expressive values were obtained with the application of hydrogel ( $4 \mathrm{~g} /$ plant) and an increase of $22.7 \%$ was obtained at the irrigation frequency of 7 days for plants without the polymer incorporation. 

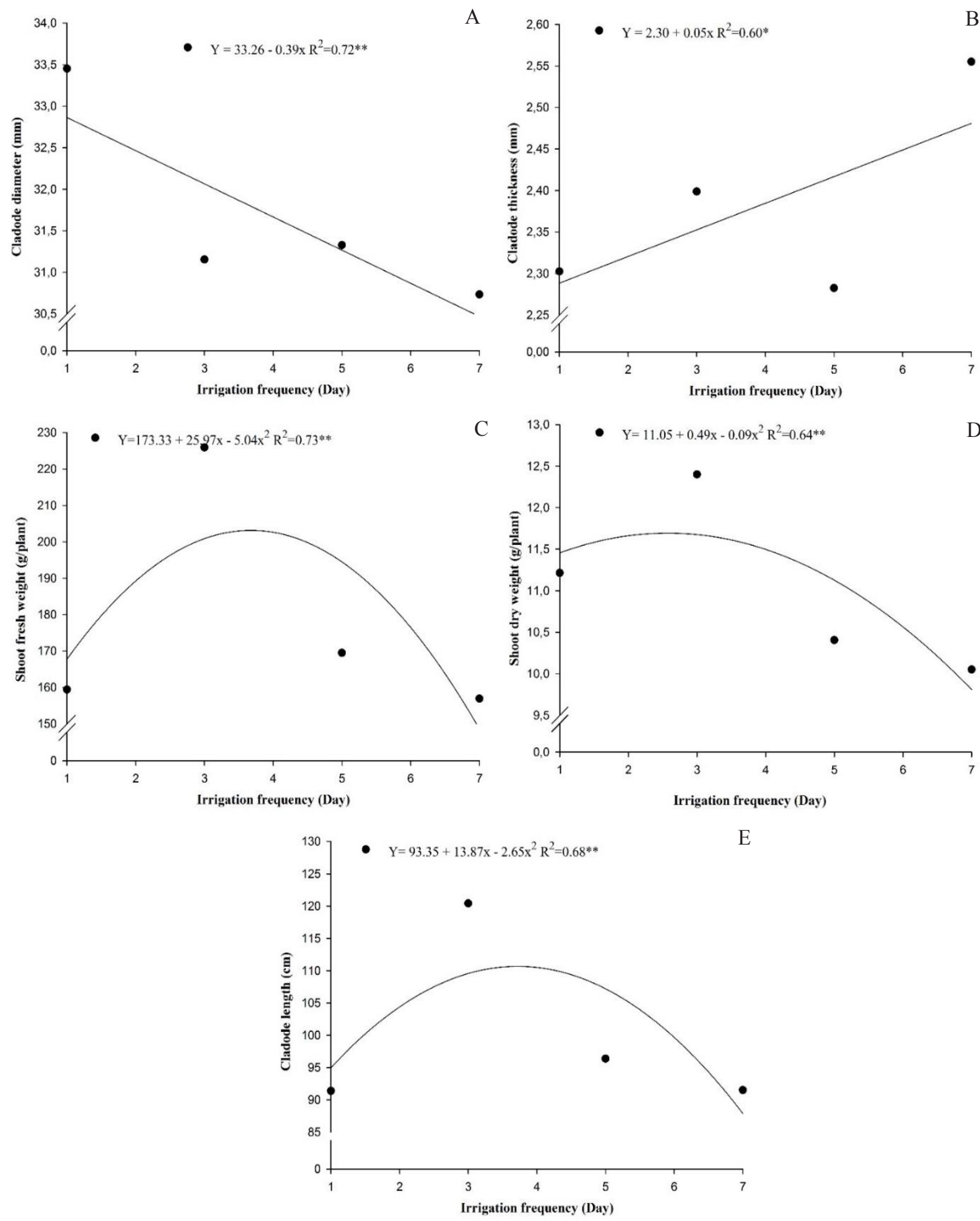

$\mathrm{E}$

Figure 1. Diameter (A), thickness (B), fresh matter (C), and dry matter (D) of the aerial part and length of the sum of cladodes (E) of white pitaya as a function of irrigation frequencies and hydrogel doses. 
The high root length of the seedlings submitted to water deficit at the irrigation frequency of 7 days may be related to a mechanism of tolerance to drought for moderate water deficit, when plants close their stomata and deepen their root system to exploit a larger substrate volume, with a consequent increase in water and nutrient absorption (Taiz et al., 2017). The application of hydrogel ( $4 \mathrm{~g} /$ plant) provided higher means for root length compared to seedlings without hydrogel addition ( $0 \mathrm{~g} / \mathrm{plant}$ ). It is related to the hydrogel capacity to provide a favorable environment for the root system development, in addition to allowing plant roots to grow within the granules of the hydrated polymer, with a higher contact surface between roots, water, and nutrients (Thomas, 2008).

The root dry matter (RDM) (Figure 2 B) had a quadratic behavior at the hydrogel doses $(0,2$, and $4 \mathrm{~g} /$ plant), with the maximum dry matter accumulation $(0.29,0.37$, and 0.32 g/plant) at irrigation frequencies of $3.7,4.3$, and 4.9 days, respectively. Later, a reduction in RDM accumulation was observed when the irrigation frequency decreased. The highest RDM accumulation was obtained at the lowest hydrogel dose (2 g/plant), with a decrease as the dose increased.

The non-incorporation of hydrogel into the substrate, i.e., the zero dose (0), resulted in the highest reductions in dry biomass (TDM) accumulation as irrigation frequency was reduced (Figure 2C). The means of treatments with 2,4 , and $6 \mathrm{~g} / \mathrm{plant}$ of hydrogel had an increasing behavior up to the irrigation frequency of 3.5, 3.3, and 3.7 days, with the point of maximum technical efficiency of $12.21,12.01$, and $12.46 \mathrm{~g} / \mathrm{plant}$, respectively, decreasing later with a reduction in irrigation frequency (Figure 2C).

The highest TDM accumulations were obtained with hydrogel incorporation associated with a reduction in irrigation frequency. This response may be associated with the polymer capacity to retain hundreds of times its mass in water and gradually release it to the plants under water deficiency conditions (Mendonça, Querido, \& Sousa, 2015; Navroski, Araujo, Reininger, Muniz, \& Oliveira Pereira, 2014). Furthermore, the addition of hydroabsorbent polymers results in higher retention of nutrients and, consequently, their higher absorption, contributing to increasing the plant biomass (Syvertsen \& Dunlop, 2004).

The seedlings had the highest means for the aerial part/root ratio (APRR) (Figure 2D) at the hydrogel dose of $6 \mathrm{~g} /$ plant, with the maximum technical efficiency of 51.76 $\mathrm{g}$ at the irrigation frequency of 3.6 days, with decreases in the APRR means with an increase in water deficit.

The trend of APRR additions at the maximum hydrogel dose is related to biometric adaptations of the plants due to water availability in the substrate, which is reflected in a modification of the dry biomass allocation between the roots and aerial part. According to De Paula Quintão Scalon, Mussury, De Mello Euzébio, Kodoma and Kissmann (2011), it is common to have a higher biomass allocation in the roots to increase water and nutrient absorption when the plants are under water stress. In addition, the decrease in water availability reduces photosynthesis, leading to a lower net rate of plant assimilation and growth. 


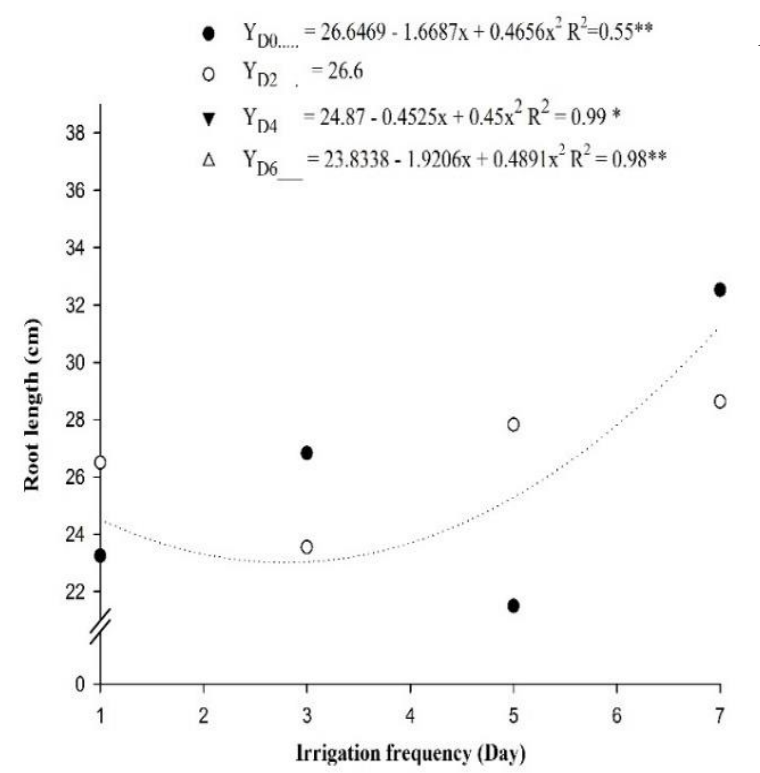

A
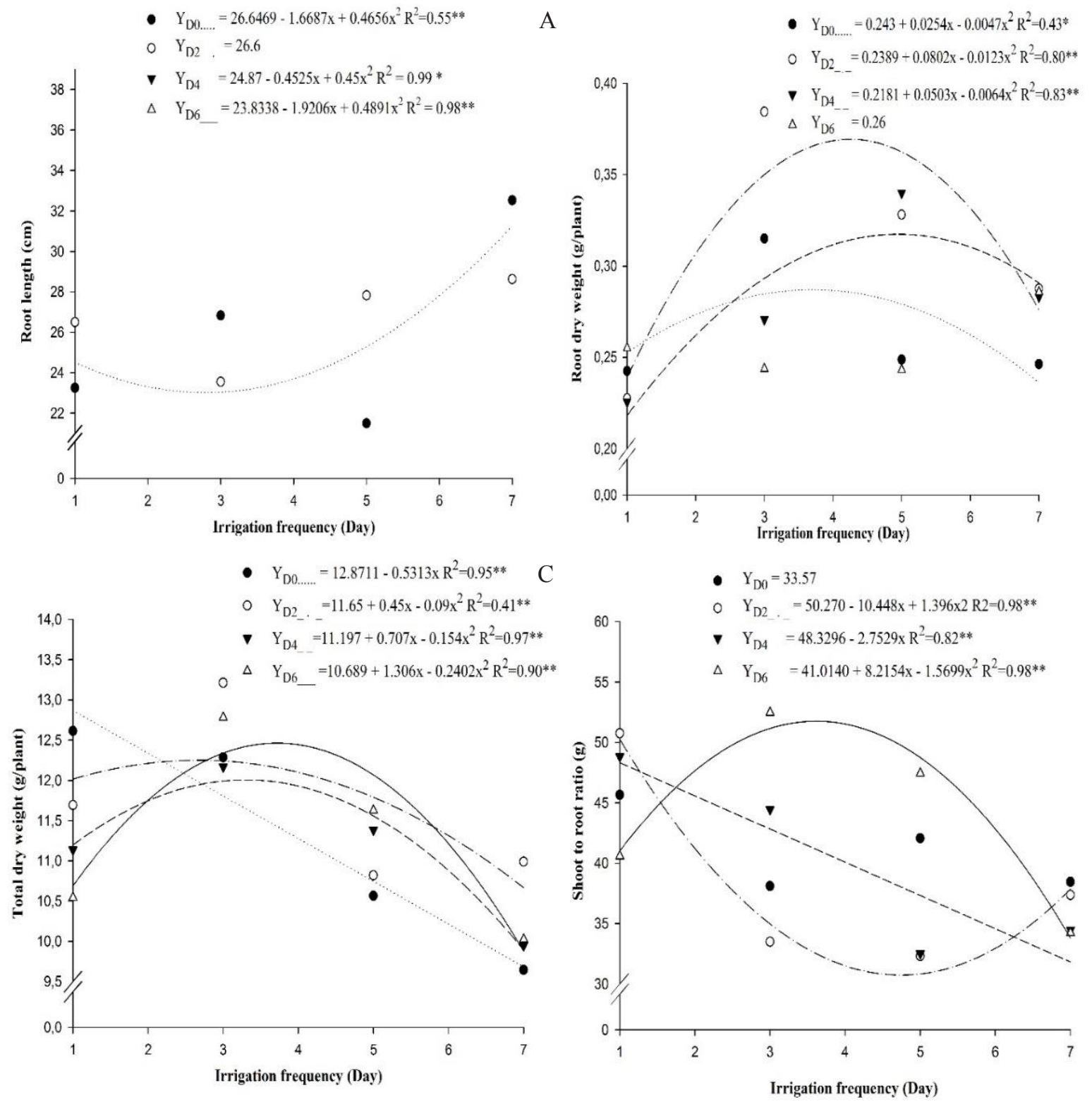

$\mathrm{D}$

Figure 2. Root system length (A), root system dry matter (B), total dry matter (C), and aerial part to root ratio (D) of white pitaya seedlings as a function of irrigation frequencies and hydrogel doses.

\section{Biochemical characteristics}

Seedlings that had the irrigation performed at frequencies of 3 to 5 days increased the synthesis of chlorophyll a, chlorophyll b, total chlorophyll, and carotenoids in the cladode compared to the daily irrigation frequency (Figure 3). The hydrogel dose of $6 \mathrm{~g} / \mathrm{plant}$ provided the highest means $(2.51,3.71$, and $1361.80 \mathrm{mg}$ $\mathrm{g} /$ plant), with increases of $19.5 \%, 12.4 \%$, and $16.8 \%$, respectively, compared to the dose of $0 \mathrm{~g} /$ plant, at irrigation frequencies of 4.2, 4.1, and 4.1 days, respectively, for chlorophyll a, total chlorophyll, and carotenoids (Figure 3A, 3C, and 3D). 

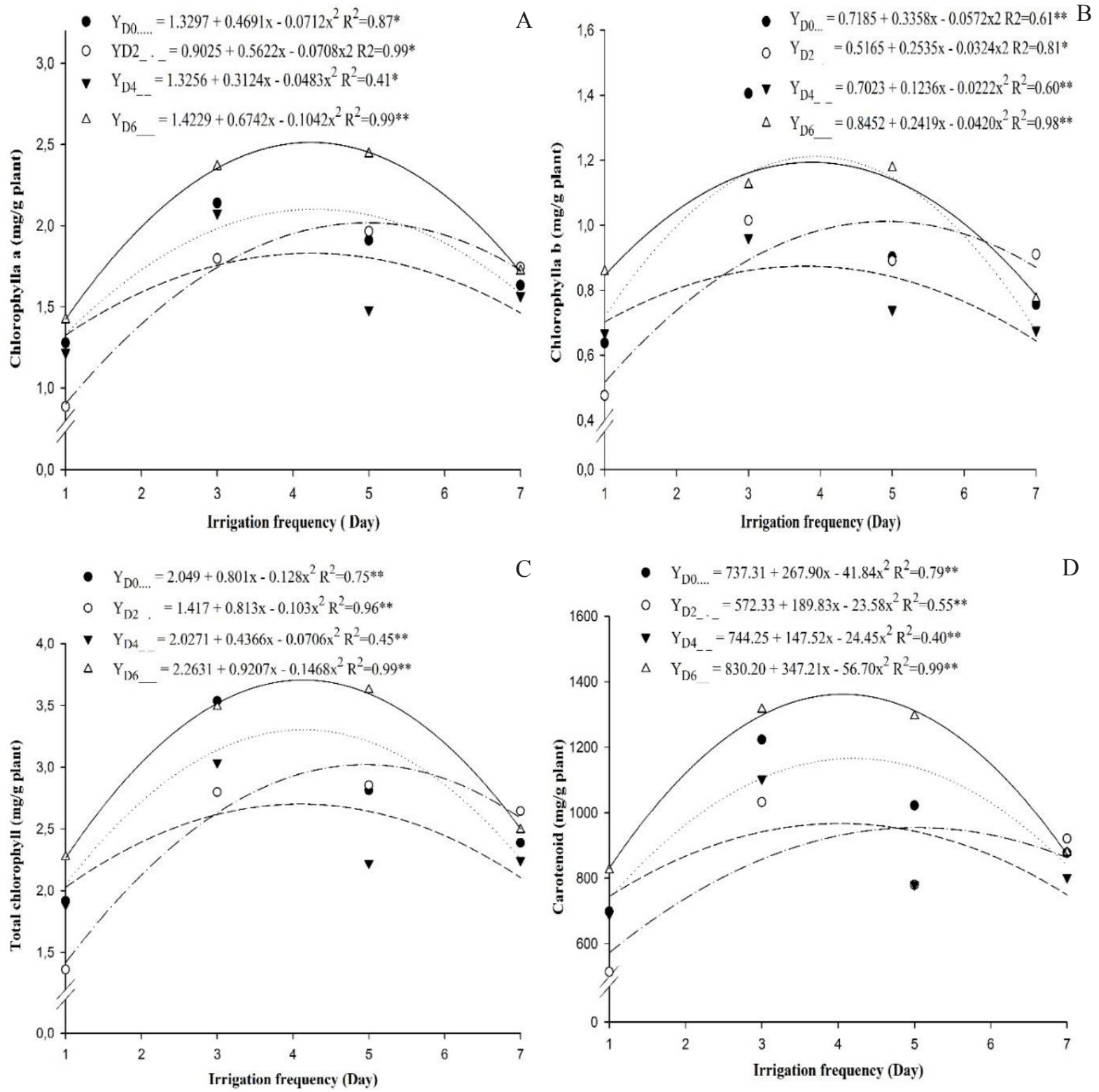

$\mathrm{C}$

- $\mathrm{Y}_{\mathrm{D} 0 \ldots . . .}=737.31+267.90 \mathrm{x}-41.84 \mathrm{x}^{2} \mathrm{R}^{2}=0.79^{* *}$

$\mathrm{D}$

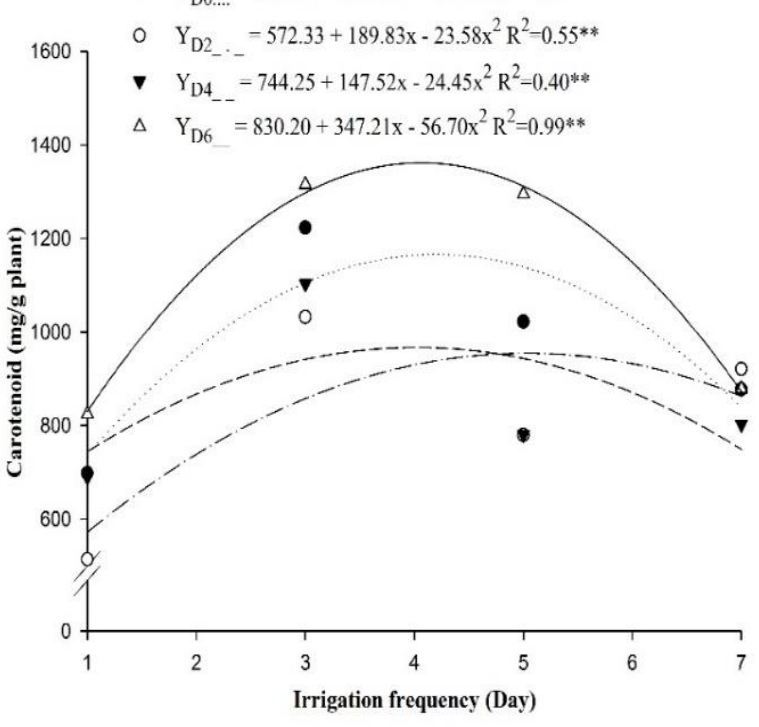

Figure 3. Chlorophyll a (A), chlorophyll b (B), total chlorophyll (C), and carotenoids (D) of white pitaya seedlings as a function of irrigation frequencies and hydrogel doses.

The absence and application of the maximum hydrogel dose ( $6 \mathrm{~g} / \mathrm{plant}$ ) promoted the highest means for chlorophyll b content, with maximum efficiency points of 1.21 and $1.19 \mathrm{mg} \mathrm{g} / \mathrm{plant}$, respectively, at the frequency of 3.9 days, with decreases in leaf concentration with an increase in water deficit (Figure 3B). All these variables were adjusted to a quadratic regression model. A reduction in the synthesis of these compounds was observed with an increase in the interval between irrigations after the point of maximum 
efficiency. Similar performance was observed between the chlorophyll accumulation and carotenoid concentration (Figure 4D) in the pitaya seedlings.

Additions in the total chlorophyll levels under adverse conditions directly reflect on the development of chloroplasts, increasing the number of thylakoids or even the number of chloroplasts to protect the photosynthetic apparatus. Chlorophyll a is the main pigment involved in photosynthesis, and its increase leads to an increase in the photosynthetic rates, thus affecting plant growth (Raven, Evert, \& Eichhorn, 2007; Mendes, Willadino, Cunha, Oliveira, \& Camara, 2011).
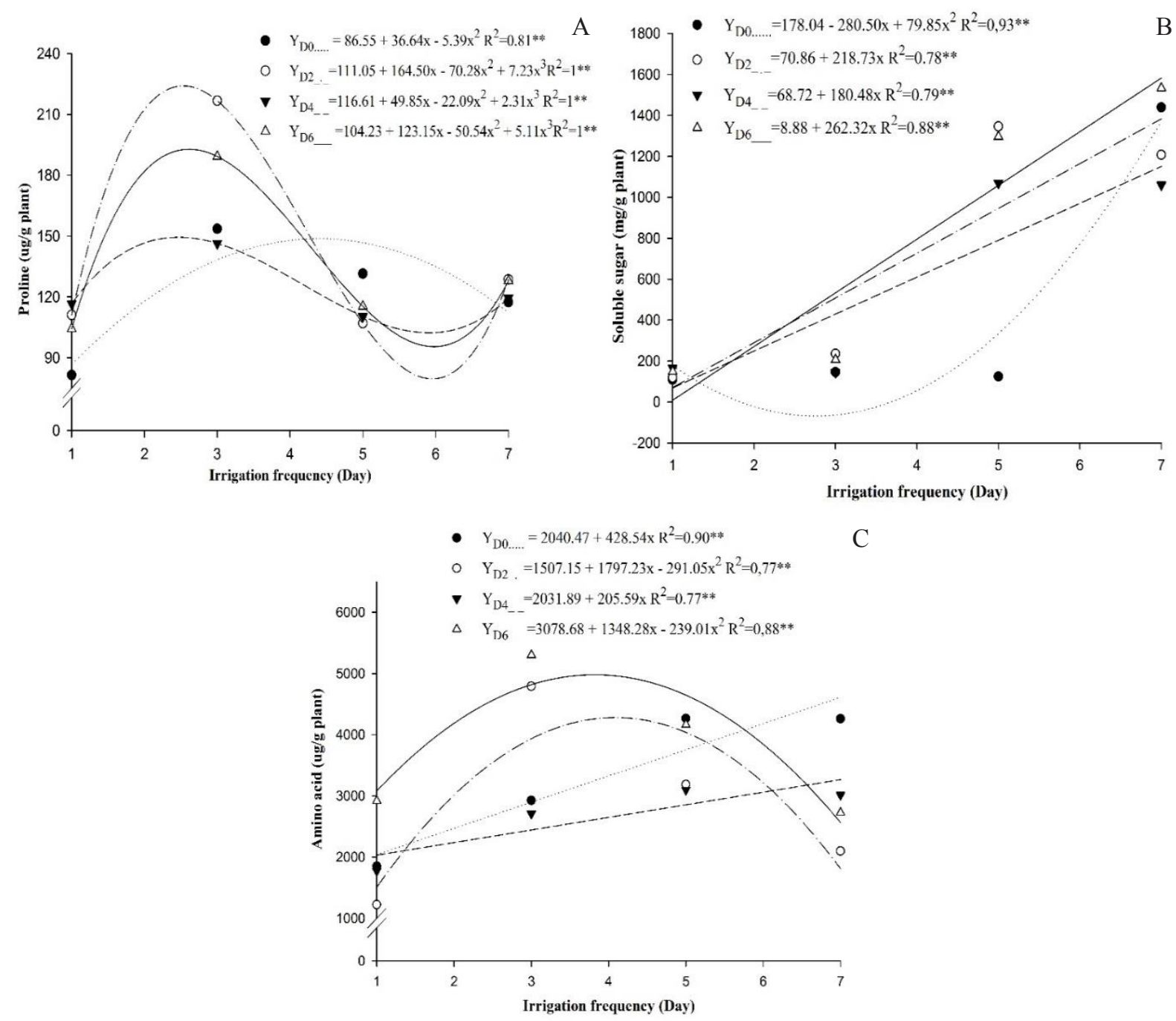

Figure 4. Proline (A), total soluble sugars (B), and total free amino acids (C) of white pitaya seedlings as a function of irrigation frequencies and hydrogel doses. 
In general, chlorophyll and carotenoid contents in pitaya plants showed a good response to the use of hydrogel, and the highest rates were observed with the presence of the maximum dose of this polymer. This result suggests that the polymer addition interferes with the supply of nutrients, consequently leading to higher absorption of essential mineral elements to photosynthesis, especially nitrogen, an element directly linked to a higher photosynthetic rate of the plant. The highest values of carotenoids were found at the 4-day irrigation frequency, which can be attributed to the fact that these pigments protect chlorophylls from photo-oxidative processes (Felippe et al., 2016).

The factors irrigation frequency (IF) and hydrogel doses (HD) $(p<0.05 ; p<0.01)$ interacted significantly for organic solutes. The response of the variables proline, soluble sugar, and amino acids (Figure 4) to water deficit varied among irrigation frequencies. Hydrogel doses ( 2 and $6 \mathrm{~g} / \mathrm{plant}$ ) provided the highest means of proline (Figure 4), with maximum technical efficiency of 224.10 (2.5 days) and $192.83 \mu \mathrm{g}$ g/plant (2.6 days), respectively, with decreases in the leaf concentration of this metabolite with increasing interval between irrigations.

Pitaya seedlings had a significant increase in the leaf concentration of soluble sugar (Figure 4B) (approximately 19, 17, and 178 times for hydrogel doses of 2, 4, and $6 \mathrm{~g} /$ plant, respectively) at the irrigation frequency of 7 days when compared to daily irrigation.

Moreover, pitaya seedlings significantly increased the leaf concentration of soluble sugar in the longest interval between irrigations ( 7 days). This response may be an indication of changes in the biochemical metabolism of the plant, causing an increase in the content of this metabolite to perform the osmotic adjustment by reducing the water potential. In addition, sugars form a viscous state in the cells capable of protecting them during periods of water shortage, reducing the biochemical processes and minimizing the activity of reactive oxygen species (ROS) (Rosa, Von Pinho, Vieira, Veiga, \& Veiga, 2005; Taiz et al., 2017).

The reduction in irrigation frequency influenced positively amino acids accumulation (Figure 4C) for hydrogel doses of 0 and $4 \mathrm{~g} /$ plant, showing increasing linear regression response and inducing higher leaf concentrations of these metabolites with increasing the interval between irrigations. Hydrogel doses of 2 and $6 \mathrm{~g} /$ plant responded to a quadratic regression model, with the highest content ( $4980.15 \mu \mathrm{g}$ g/plant) obtained at the maximum hydrogel dose ( $6 \mathrm{~g} / \mathrm{plant}$ ) and irrigation frequency of 3.8 days, decreasing later with an increase in the interval between irrigations.

The higher accumulation of total amino acids, resulting from the increase in the interval between irrigations, may be due to the osmotic adjustment performed through the increase in the concentration of this metabolite in the cells to maintain the turgor and balance of the hydric potential in the cell, being one of the main responses of plants to water stress (Taiz et al., 2017).

\section{Nutritional characteristics}

The nitrogen content in pitaya seedlings had a significant effect on the isolated factors irrigation frequency (IF) and hydrogel doses (HD) $(p<0.01 ; p<0.05)$. The macronutrients 
potassium (K), phosphorus (P), calcium $(\mathrm{Ca})$, and magnesium $(\mathrm{Mg})$ had a significant interaction between the factors irrigation frequency (IF) and hydrogel doses (HD) ( $p<$ 0.05) (Supplementary Material: Table 2).

The $\mathrm{N}$ content (Figure $5 \mathrm{~B}$ ) tended to increase until the hydrogel dose of $1.6 \mathrm{~g}$. A subsequent increase in the hydrogel dose led to a reduction in $\mathrm{N}$ accumulation in the seedlings. The factor IF (Figure 5A) showed the maximum $\mathrm{N}$ accumulation at the irrigation frequency of 3.9 days, with decreases as the interval between irrigations increased.

Seedlings that did not have hydrogel incorporation into the substrate presented the lowest means for potassium content (Figure $6 \mathrm{~A})$. The highest accumulation in $\mathrm{K}$ content of $0.77 \mathrm{~g} /$ plant was obtained with the use of $2 \mathrm{~g} /$ plant of the hydrogel at the irrigation frequency of 4.7 days, with a $13 \%$ increase in $\mathrm{K}$ content.

The hydrogel addition to the substrate up to a certain limit increased the $\mathrm{K}$ content, possibly because the hydrogel retains a certain amount of this nutrient and makes it available to the plant for longer periods. The frequency of irrigation showed a trend of $\mathrm{K}$ accumulation as the irrigation frequency was reduced to 4.7 days, constituting the worst means found at the daily irrigation. Gomes (2001) reported that an increase in moisture in the substrate causes less nutrient absorption by the plant. The increase in $\mathrm{K}$ content at longer intervals between irrigations may have occurred due to the osmotic adjustment promoted by this element in response to low water availability in the substrate.

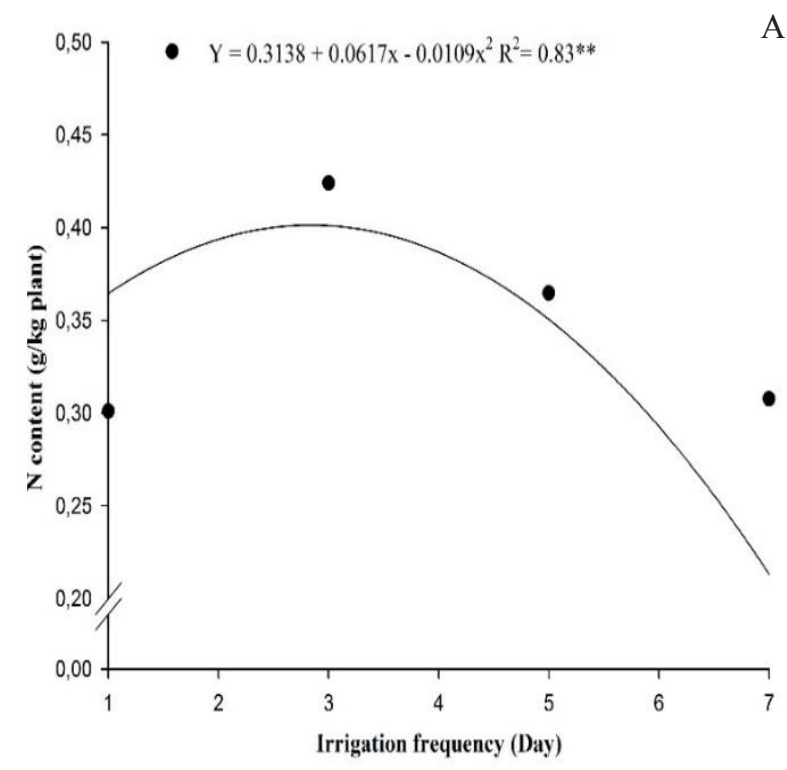

A

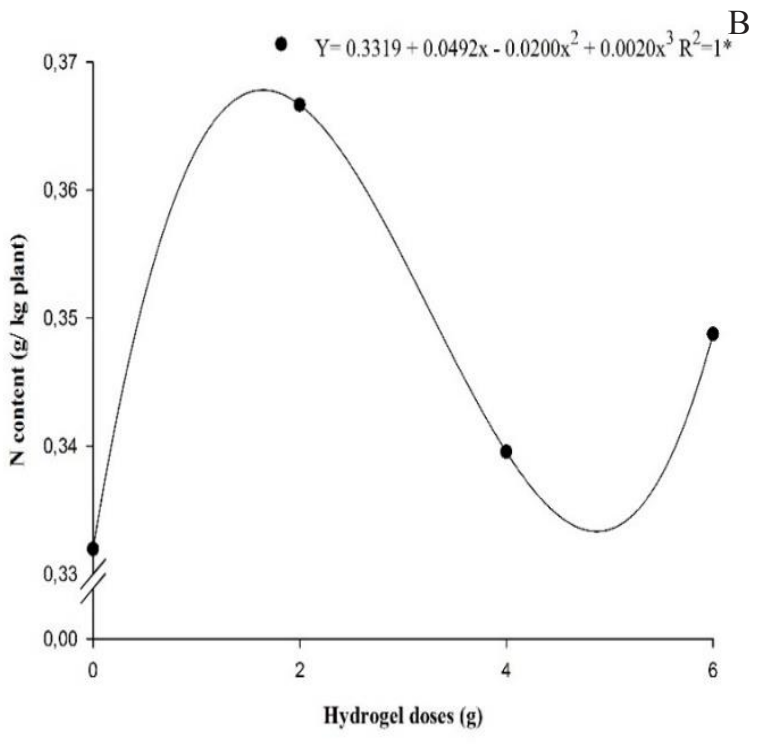

Figure 5. Nitrogen content as a function of irrigation frequencies $(A)$ and hydrogel doses $(B)$ of white pitaya seedlings. 
The reduction in $\mathrm{P}, \mathrm{Ca}$, and $\mathrm{Mg}$ contents (Figure 6B, 6C, and 6D) in white pitaya seedlings was significant as the interval between irrigations increased. The highest accumulations in plant tissues were obtained at the daily irrigation frequency with 0.09 , 0.27 , and $0.31 \mathrm{~g} \mathrm{~kg} /$ plant, respectively, at the hydrogel dose of $6 \mathrm{~g} /$ plant for three elements, with a significant reduction as the interval between irrigations increased. The increase in $\mathrm{P}, \mathrm{Ca}$, and $\mathrm{Mg}$ contents in white pitaya seedlings that received the highest doses of the polymer can be attributed to the higher water availability in the substrate.

In general, the incorporation of the hydro-absorbent polymer to the substrate has provided an improvement in nutrient content, reflected positively in several characteristics of the development of white pitaya seedlings. According to Oliveira, Rezende, Martinez and Miranda (2004), the hydrogel incorporation into the substrate provides an improvement in the physical properties of the substrates, with reflection in the higher availability and absorption of nutrients by plants.

The hydrogel incorporation allowed increasing the interval between irrigations by one day, without damage to the seedling development. It can be a valuable resource, especially given that water scarcity is one of the biggest problems facing producers in the northeast region. In addition, the water can be used for other stages of crop development, reducing seedling production costs. 

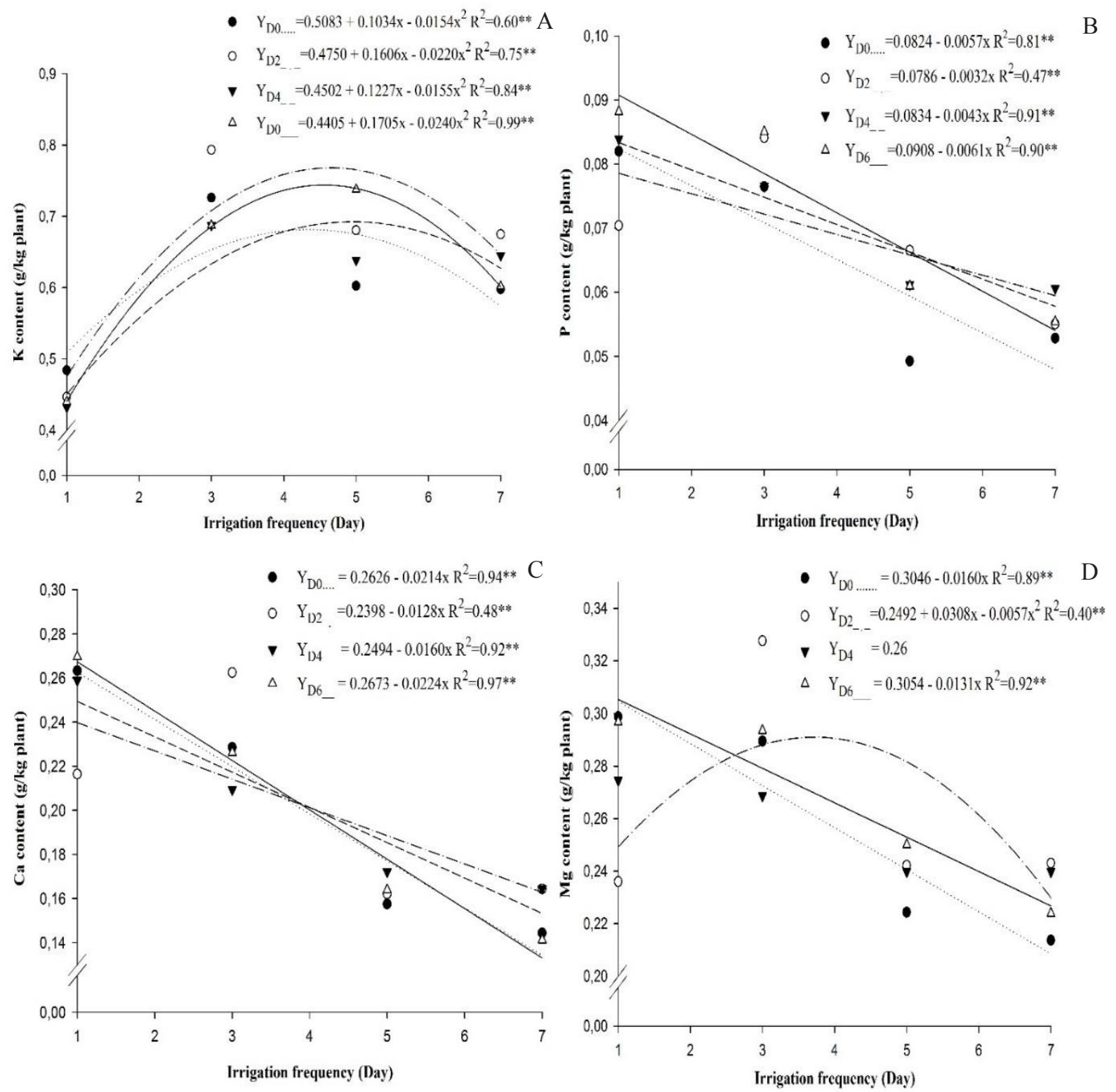

Figure 6. Potassium (A), phosphorus (B), calcium (C), and magnesium (D) of white pitaya seedlings as a function of irrigation frequencies and hydrogel doses.

\section{Conclusion}

Pitaya seedlings had a higher development when an irrigation frequency of about 3 days was used.

For the test conditions, the hydrogel application of $6 \mathrm{~g} / \mathrm{plant}$ had a positive effect on the accumulation of dry biomass, photosynthetic pigments, and organic and inorganic solutes.

The hydrogel incorporation allowed increasing the interval between irrigations by 1 day without damage to the seedling development. 


\section{Acknowledgments}

The authors would like to thank CAPES (Coordination for the Improvement of Higher Education Personnel) and CNPq (National Council for Scientific and Technological Development) for financial support.

\section{References}

Abdallah, A. M. (2019). The effect of hydrogel particle size on water retention properties and availability under water stress. International Soil and Water Conservation Research, 7(3), 275-285. doi: 10.1016/j. iswcr.2019.05.001

Aleman, C. C., Campos, F. B., \& Mantovani, E. C. (2020). Precision tools for irrigation management of tomato seedlings. Bioscience Journal, 36(2). doi: 10.14393/ BJ-v36n2a2020-43252

Almeida, E. I. B. (2015). Sombreamento em ecofisiologia, produção e propagação de pitaya vermelha. Tese de doutorado, Universidade Federal do Ceará, Fortaleza, CE, Brasil.

Arnon, D. I. (1949). Copper enzymes in isolated chloroplasts. Polyphenoloxidase in beta vulgaris. Plant Physiology, 24(1), 1. doi: 10.1104/pp.24.1.1

Bernardi, M. R., Sperotto, M., Jr., Daniel O., \& Vitorino, A. C. T. (2012). Growth of seedlings of Corymbia citriodora due to the use of hydrogel and fertilization, Cerne, 18(1), 67-74. doi: 10.1590/S01047760201200100009

Carvalho, R. P., Cruz, M. C. M., \& Martins, L. M. (2013). Frequency of irrigation using hydro-absorbent polymer in the production of yellow passion fruit seedlings. Revista Brasileira de Fruticultura, 35(2), 518-526. doi: 10.1590/ S0100-29452013000200022

Companhia Nacional de Abastecimento (2020). Boletim Hortigranjeiro. Recuperado de http://dw.ceasa.gov. br/\#

Cruz, M. C. M., Hafle, O. M., Ramos, J. D., \& Ramos, P.S. (2008). Development of tangerine tree rootstock 'Cleópatra'. Revista Brasileira de Fruticultura, 30(2), 471-475. doi: 10.1590/ S0100-29452008000200035

De Paula Quintão Scalon, S., Mussury, R. M., De Mello Euzébio, V. L., Kodama, F. M., \& Kissmann, C. (2011). Water stress in metabolism and initial growth of mutambo (Guazuma ulmifolia Lam.) seedlings. Ciência Florestal, 21(4), 655-662.

Empresa Brasileira de Pesquisa Agropecuária (2013). Sistema Brasileiro de Classificação de Solos (3a ed.). Brasília: EMBRAPA Solos.

Ennajeh, M., Vadel, A. M., Cochard, H., \& Khemira, H. (2010). Comparative impacts of water stress on the leaf anatomy of a drought-resistant and a drought-sensitive olive cultivar. The Journal of Horticultural Science and Biotechnology, 85(4), 289-294. doi: 10. 1080/14620316.2010.11512670

Felippe, D., Navroski, M. C., Sampietro, J. A., Frigotto, T., Albuquerque, J. A., Mota, C. S., \& Pereira, M. O. (2016). Efeito do hidrogel no crescimento de mudas de Eucalyptus benthamii submetidas a diferentes frequências de irrigação. Floresta, 46(2), 215-225. doi: 10.1042/bj0570508

Ferreira, E. B., Cavalcanti, P. P., \& Nogueira, D. A. (2018). Package 'expdes.pt': experimental designs. $R$ package version 1.2.0. 
Retrieved from https://cran.r-project.org/ package $=$ ExpDes.pt

García Aguilar, M., Terrazas, T., \& Arias, S. (2009). Anatomía caulinar de tres especies del género hylocereus (Berger) Britton \& Rose (cactaceae) en México. Revista Fitotecnia Mexicana, 32(3), 201-208.

Gomes, J. M. (2001). Parâmetros morfológicos na avaliação da qualidade de mudas de Eucalyptus grandis, produzidas em diferentes tamanhos de tubetes e de dosagens de $N-P-K$. Tese de doutorado, Universidade Federal de Viçosa, Viçosa, MG, Brasil. Recuperado de http://www. locus.ufv.br/handle/123456789/11393

Hafle, O. M., Cruz, M. do C. M., Ramos, J. D., Ramos, P. S., \& Santos, V. A. (2008). Produção de mudas de maracujazeirodoce através da estaquia utilizando polímero hidrorretentor. Revista Brasileira de Ciências Agrárias, 3(3), 232-236. doi: 10.5039/agraria.v3i3a292

Larcher, W. (2000). Plant ecophysiology. São Carlos, SP: Rima Artes e Textos.

Lichtenthaler, H. K. (1987). Chlorophylls and carotenoids: pigments of photosynthetic biomembranes. Methods in Enzymology, 148, 350-382. doi: 10.1016/0076-6879 (87)48036-1

Mendes, B. S. D. S., Willadino, L., Cunha, P. C. da, Oliveira, R. A. de, Fo, \& Camara, T. R. (2011). Mecanismo fisiológicos e bioquímicos do abacaxi ornamental sob estresse salino. Revista Caatinga, 24(3), 71-77.

Mendonça, T. G., Querido, D. C. M., \& Souza, C. F. (2015). Efficiency of polymerhydrogel in maintaining soil moisture in lettuce. Revista Brasileira de Agricultura Irrigada, 9(4), 239-245.
Monteiro, J. L. L. Neto, Araújo, W. F., Chagas, E. A., Silva Siqueira, R. H. da, Oliveira, G. A., \& Rodriguez, C. A. (2017). Hydrogels in Brazilian agriculture. Revista Agro@ mbiente On-line, 11(4), 347-360. doi: 10.18227/1982-8470ragro.v11i4.4130

Moreira, R. A., Ramos, J. D., Cruz, M. D. C. M. da, Villar, L., \& Hafle, O. M. (2010). Efeito de doses de polímero hidroabsorvente no enraizamento de estacas de amoreira. Agrarian, 3(8), 133-139.

Navroski, M., Araújo, M. M., Reiniger, L. R. S., Muniz, M. F. B., \& Oliveira Pereira, M. de. (2014). Influência do hidrogel no crescimento e no teor de nutrientes das mudas de Eucalyptus dunnii. Floresta, 45(2), 315-328. doi: 10.5380/ rf.v45i2.34411

Oliveira, R. A. D., Rezende, L. S., Martinez, M. A., \& Miranda, G. V. (2004). Influência de um polímero hidroabsorvente sobre a retenção de água no solo. Revista Brasileira de Engenharia Agrícola e Ambiental, 8(1), 160-163. doi: 10.1590/ S1415-43662004000100023

R Core Team (2018). A language and environment for statistical computing. Vienna, Austria: $\mathrm{R}$ Foundation for Statistical Computing. Retrieved from http://www.R-project.org

Raven, P. H., Evert, R. F., \& Eichhorn, S. E. (2007). Plant biology (7nd ed.). Rio de Janeiro: Guanabara Koogan.

Ribeiro, M. D. N. O., Carvalho, S. P. D., Pereira, F. J., \& Castro, E. M. D. (2012). Leaf anatomy of the cassava as related to potential for tolerance to different environmental conditions. Revista Ciência Agronômica, 43(2), 354-361. doi: 10.1590/S180666902012000200019 
Rosa, S. D. V. F. D., Von Pinho, É. V. R., Vieira, E. S. N., Veiga, R. D., \& Veiga, A. D. (2005). Enzimas removedoras de radicais livres e proteínas lea associadas à tolerância de sementes milho à alta temperatura de secagem. Revista Brasileira de Sementes, 27(2), 91-101. doi: 10.1590/S0101-312 22005000200014

Silva, A., Martins, A. B. G., \& Cavallari, L. D. L. (2011). Fruit quality of pitaya as a function of pollination time, pollen source and environment for cultivation. Revista Brasileira de Fruticultura, 33(4), 1162-1168. doi: 10.1590/S0100-29452 011000400014

Silveira, J. A. G., Almeida Viégas, R. de, Rocha, I. M. A. da, Moreira, A. C. D. O. M., Azevedo Moreira, R. de, \& Oliveira, J. T. A. (2003). Proline accumulation and glutamine synthetase activity are increased by saltinduced proteolysis in cashew leaves. Journal of Plant Physiology, 160(2), 115123. doi: 10.1078/ 0176-1617-00890

Syvertsen, J. P., \& Dunlop, J. M. (2004). Hydrophilic gel amendments to sand soil can increase growth and nitrogen uptake efficiency of citrus seedlings. HortScience, 39(2), 267-271. doi: 10.21 273/HORTSCI.39. 2.267
Taiz, L., Zeiger, E., Moller, I. M., \& Murphy, A. (2017). Physiology and plant development (6nd ed.). Porto Alegre: Artmed.

Teixeira, P. C., Donagemma, G. K., Fontana, A., \& Teixeira, W. G. (2017). Manual of soil analysis methods (3a ed.). Brasília, DF: EMBRAPA Solos.

Thomas, D. S. (2008). Hydrogel applied to the root plug of subtropical eucalypt seedlings halves transplant death following planting. Forest Ecology and Management, 255(3-4), 1305-1314. doi: 10.1016/j.foreco. 2007.10.035

Witham, F. H., Blaydes, D. F., \& Devlin, R. M. (1971). Experimentos em fisiologia vegetal.

Yemm, E. W., \& Willis, A. (1954). The estimation of carbohydrates in plant extracts by anthrone. Biochemical Journal, 57(3), 508-514. doi: 10.1042/bj0570508

Yemm, E. W., Cocking, E. C., \& Ricketts, R. E. (1955). The determination of amino-acids with ninhydrin. Analyst, 80(948), 209-214. doi: 10.1039/AN9558000209 